\title{
Pendekatan Numerik pada model Isotropic dan Anisotropic Diffusion untuk Mendeteksi Tepi pada Pengolahan Citra
}

\author{
Iryanto ${ }^{1}$, F. Fristella ${ }^{2}$, P. H. Gunawan ${ }^{3}$ \\ 1 Teknik Informatika, Politeknik Negeri Indramayu, Jl. Raya Lohbener Lama No. 08 Indramayu, \\ Indramayu 45252, Indonesia \\ 2 Sains Komputasi, Fakultas Matematika dan Ilmu Pengetahuan Alam, Institut Teknologi Bandung, \\ Jalan Ganesha 10, Bandung 40132, Indonesia \\ ${ }^{3}$ School of Computing, Telkom University, Jalan Telekomunikasi Terusan Buah Batu, Bandung 40257, \\ Indonesia \\ ${ }^{1}$ iryanto.math@yahoo.com ${ }^{2}$ friskafristella@ymail.com ${ }^{3}$ phgunawan@telkomuniversity.ac.id
}

\section{Ringkasan}

The aim of this paper is devoted to define the best edge detection model from the anisotropic and heat diffusion model in image processing. The anisotropic diffusion model is known as the Perona-Malik model which has some flux functions. In order to approximate the solution for both proposed models, the discretization of the models is used is the finite difference method for approximating the spatial and time domains. The numerical results of anisotropic diffusion model are shown better than the heat diffusion model for the sharpness of the image, in this case to prevent the significant parts of the image content, typically edges, lines, etc. The measurement in this paper uses two approach which are the histogram image and Peak Signal to Noise Ratio (PSNR). Values of PSNR for isotropic and anisotropic diffusion model are obtained $6.1745 \mathrm{~dB}$, dan $6.1833 \mathrm{~dB}$ respectively.

Keywords: Image processing, heat equation, Perona-Malik equation, finite difference method, anisotropic diffusion, isotropic diffusion.

\begin{abstract}
Abstrak
Tujuan dari penulisan ini adalah untuk menentukan model deteksi tepi terbaik dari model anisotropic diffusion dan persamaan panas isotropic diffusion pada pengolahan citra. Model anisotropic diffusion disebut sebagai persamaan Perona-Malik yang memiliki berbagai fungsi fluks dalam persamaannya. Untuk menghampiri solusi persamaan anisotropic dan isotropic diffusion secara numerik, metode beda hingga digunakan dalam mendiskritkan domain spasial dan waktu dari model yang digunakan. Hasil numerik menggunakan model anisotropic diffusion menghasilkan gambar yang lebih tajam dibandingkan menggunakan model persamaan panas, dalam hal ini untuk mempertahankan garis tepi pada citra. Hasil pengukuran menggunakan profil histogram dan Peak Signal to Noise Ratio (PSNR) untuk melihat perbedaan masing-masing hasil simualsi numerik. PSNR pada citra menggunakan model isotropic dan anisotropic diffusion berturut-turut didapatkan sebesar $6.1745 \mathrm{~dB}$, dan $6.1833 \mathrm{~dB}$.
\end{abstract}

Kata Kunci: Pengolahan citra, persamaan panas, persamaan Perona-Malik, metoda beda hingga, anisotropic diffusion, isotropic diffusion.

\section{LATAR BELAKANG}

$\mathbf{P}$

ENGOLAHAN citra atau Image Processing merupakan teknik dalam pemrosesan citra atau gambar digital menjadi gambar yang memiliki informasi khusus yang diinginkan. Aplikasi dari pengolahan citra digital untuk membantu kehidupan manusia sudah banyak digunakan [2]. Sebagai contoh, dalam membantu sistem keamanan untuk mengidentifikasi kriminalitas pada gambar CCTV (closed-circuit television) yang memiliki kualitas gambar rendah, pengolahan citra digunakan untuk mempertajam gambar tersebut sehingga mempermudah petugas keamanan untuk mengidentifikasi pelaku kriminalitas. Selain itu, 
IRYANTO ET.AL.

PENDEKATAN Numerik PADA MODEL ISOTROPIC...

pengolahan citra juga sangat membantu dalam bidang kesehatan seperti untuk mengidentifikasi penyakit yang dihasilkan dari gambar telapak tangan [11].

Pada praktiknya, bidang aplikasi pengolahan citra sangat luas. Selain bidang - bidang di atas, monitoring dan pemetaan suatu area adalah salah satu contoh bidang aplikasi pengolahan citra berikutnya. Misalnya untuk pemetaan lahan pertanian dan bidang agrikultur [16]-[19], pemetaan tanah longsor [10], [13], pemetaan polusi air [25], pemetaan pulau kecil [14], dan pemetaan lahan bencana [1].

Dalam perkembangan pengolahan citra, model persamaan differensial yang dikenalkan pada akhir tahun 80s dan awal tahun 90s berpengaruh sangat besar pada kajian matematis di bidang tersebut [7]. Model yang pertama berdasarkan pada model varisional seperti pada [9] sedangkan model kedua berdsarakan pada penurunan gradien lihat [12]. Model yang kedua ini juga dikenal dengan persamaan Perona-Malik atau anistropic diffusion yang merupakan persamaan partial differential equations (PDE) tipe hiperbolik [2].

Kajian tentang penggunaan PDE, model anistropic diffusion, untuk peningkatan kualitas citra digital telah banyak dikaji. Pendekatan numerik untuk menyelesaikan PDE pada umumnya didominasi oleh skema beda hingga, elemen hingga, atau volum hingga. Misalnya, [6] menggunakan model forward dan backward anistropic diffusion dengan pendekatan numerik elemen hingga. Skema implisit dan semiimplisit volum hingga digunakan oleh [4] untuk menyelesaikan masalah tersebut. Selain skema-skema tersebut, dalam menyelesaikan masalah peningkatan kualitas citra pendekatan numerik transformasi diskrit Fourier [3] dan diskritisasi quasi-interpolasi wavelet [21] juga digunakan.

Hal penting dalam pengolahan citra adalah penyaringan informasi dari citra tersebut, informasi yang harus dipertahankan seperti garis tepi, dan informasi yang akan dikaburkan yaitu derau (noise). Hasil yang disajikan di [12] menunjukkan bahwa model ini dapat mempertahankan garis tepi untuk waktu yang lama. Selain itu, deteksi garis tepi ini juga lebih baik dibandingkan dengan deteksi tepi dengan pendekatan deteksi garis tepi linier Canny [23].

Makalah ini difokuskan untuk membahas model anisotropic diffusion dan persamaan panas pada pengolahan citra untuk mendapatkan hasil citra atau gambar yang lebih tajam. Dalam hal ini penulis akan melihat model deteksi tepi terbaik dari kedua model tersebut. Model anisotropic diffusion dan persamaan panas dalam pengolahan citra merupakan persamaan diferensial parsial (PDP) tipe parabolik berdimensi dua. Solusi dari persamaan PDP akan dihampiri dengan menggunakan metode beda hingga, metode numerik yang paling sederhana, mudah diimplementasikan, serta akurat.

Penulisan makalah ini disusun sebagai berikut, pada Bab II, persamaan matematika dari model anisotopic diffusion dan persamaan panas akan dijelaskan secara rinci. Bab III membahas mengenai metode numerik untuk mendiskritkan model matematika yang digunakan. Pembahasan tentang penelitian terkait dipaparkan pada Bab IV. Hasil dan diskusi dibahas pada Bab V. Terakhir, kesimpulan akan dipaparkan pada Bab VI.

\section{Model Matematika}

\section{A. Isotropic Diffusion}

Model Isotropic Diffusion banyak digunakan sebagai model matematis dalam pengolahan citra [24]. Secara umum persamaan ini dapat dituliskan ke dalam

$$
\partial_{t} I(x, y, t)=\nabla \cdot(\Psi(I, x, y, t) \nabla I(x, y, t))
$$

dengan $\partial$ merupakan notasi turunan parsial, $\nabla=\left(\partial_{x}, \partial y\right)$ menyatakan operator divergensi berdimensi-2 dan $\Psi$ menyatakan fungsi difusivitas. Fungsi $\Psi$ dapat berupa konstanta atau fungsi skalar, koordinat, atau tensor yang bergantung pada model yang digunakan [24]. Fungsi $I$ menyatakan citra yang diolah, variabel $x, y \in \mathbb{R}$ dan $t$ menyatakan ruang pada arah $\mathrm{x}$ dan $\mathrm{y}$, dan waktu secara berurutan. 
Jika fungsi $\Psi$ didefiniskan menjadi sebuah konstanta dengan $\Psi=1$, maka persamaan (1) dapat dituliskan menjadi model linier sederhana, yaitu menjadi persamaan panas (heat equations). Berikut persamaan panas dengan syarat awal $I_{0}(x, y)$

$$
\left\{\begin{array}{l}
\partial_{t} I=\nabla^{2} I \quad \text { pada } \Omega \times(0,+\infty) \\
I(x, y, 0)=I_{0}(x, y) \quad \text { pada } \Omega
\end{array}\right.
$$

dengan $\nabla^{2}=\left(\partial_{x x}+\partial_{y y}\right), \Omega=\left[0, L_{x}\right] \times\left[0, L_{y}\right]$ menyatakan domain citra dua dimensi dengan $L_{x}$, dan $L_{y}$ merupakan panjang domain pada arah $x$ dan $y$ secara berurutan (lihat Gambar 1). Persamaan (2) dikenal sebagai isotropic diffusion.

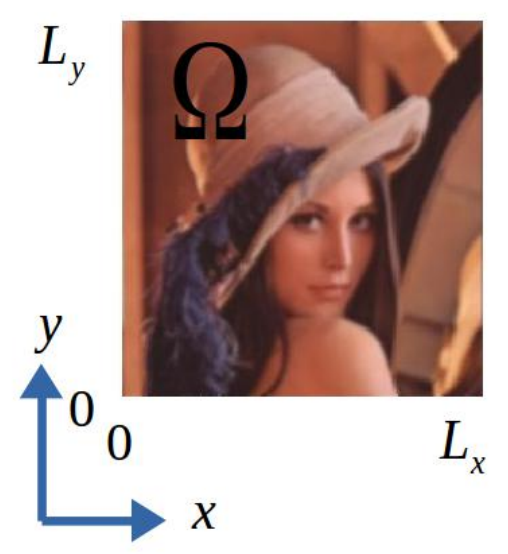

Gambar 1: Contoh domain $(\Omega)$ dari sebuah gambar Lena.

Solusi persamaan panas (2) dapat ditulis secara eksplisit yakni:

$$
I(\mathbf{x}, t)=\int_{\Omega} S(\mathbf{x}-\overline{\mathbf{x}}, t) I_{0}(\overline{\mathbf{x}}) d \overline{\mathbf{x}}
$$

dengan $\mathbf{x}=(x, y), \overline{\mathbf{x}}=(\bar{x}, \bar{y})$, dan $S(\mathbf{x}, t)$ menyatakan fungsi Green yaitu

$$
S(\mathbf{x}, t)=\frac{1}{\sqrt{4 \pi t}} \exp \left(-\mathbf{x}^{2} / 4 t\right) \quad t>0 .
$$

Dari persamaan (4), dapat dikatakan bahwa solusi persamaan panas merupakan hasil konvolusi antara citra awal dengan suatu fungsi kernel tertentu (fungsi Green/Gaussian).

\section{B. Anisotropic Diffusion}

Penghalusan (smoothing) citra dengan pendekatan persamaan panas (2), yang tidak lain adalah hasil dari konvolusi citra awal dengan suatu fungsi Green/Gaussian memiliki beberapa kekurangan, satu diantaranya adalah metoda ini kurang baik dalam preservasi garis tepi. Persamaan ini tidak hanya menghaluskan derau (noise) pada citra, tetapi juga mengaburkan informasi penting seperti garis tepi citra [22], [23].

Untuk mengatasi permasalahan tersebut, Pietro Perona dan Jitendra Malik [12] memperkenalkan model PDE lain berupa bentuk non-linier, yaitu dengan mendefinisikan suatu fungsi difusivitas atau fluks $(\Psi)$ yang dapat mengatur laju difusi untuk semua pixel pada citra. Adapun fungsi fluks tersebut adalah

$$
\begin{aligned}
& \Psi(\|\nabla I\|)=\exp \left(\frac{-\|\nabla I\|}{\kappa^{2}}\right), \\
& \Psi(\|\nabla I\|)=\frac{1}{1+(\|\nabla I\| / \kappa)^{2}} .
\end{aligned}
$$

Selain mengatur laju difusi, fungsi difusivitas (5) atau (6) juga mengatur tingkat kehalusan, kekaburan, dan preservasi garis tepi. Dalam hal ini besar kecilnya pengaruh tersebut ditentukan oleh nilai parameter $\kappa$ (kappa). 
IRYANTO ET.AL.

PENDEKATAN Numerik PADA MODEL ISOTROPIC...

Dapat dilihat pada persamaan (5) dan (6), untuk nilai $\kappa$ yang sangat besar, solusi yang dihasilkan akan mendekati solusi persamaan panas. Sehingga dengan syarat awal $I_{0}(x)$, persamaan Perona-Malik (atau disebut sebagai anisotropic diffusion) dapat dinyatakan sebagai berikut

$$
\left\{\begin{array}{l}
\partial_{t} I=\nabla \cdot\left(\Psi\left(|\nabla I|^{2}\right) \nabla I\right) \quad \text { pada } \Omega \times(0,+\infty) \\
I(x, y, 0)=I_{0}(x, y) \quad \text { pada } \Omega
\end{array} .\right.
$$

Selanjutnya, pada Bab III, diskritisasi persamaan (2) dan (7) menggunakan persamaan beda hingga akan dijelaskan dengan rinci.

\section{SKEMA NUMERIK}

Solusi numerik untuk menghampiri solusi persamaan (2) dan (7) sudah banyak dipaparkan pada beberapa referensi. Misalnya, solusi numerik persamaan (2) diperoleh dengan pendekatan penurunan gradien (gradient descent atau lebih dikenal sebagai metode steepest descent) dan pendekatan transformasi Fourrier oleh [5]. Sedangkan, pada makalah lain (lihat [21]), diskritisasi quasi-interpolasi wavelet digunakan untuk menyelesaikan persamaan (7). Untuk lebih mudahnya, di sini penulis menggunakan pendekatan metode beda hingga (forward time center space) yaitu metode numerik yang paling sederhana, mudah diimplementasikan, serta akurat.

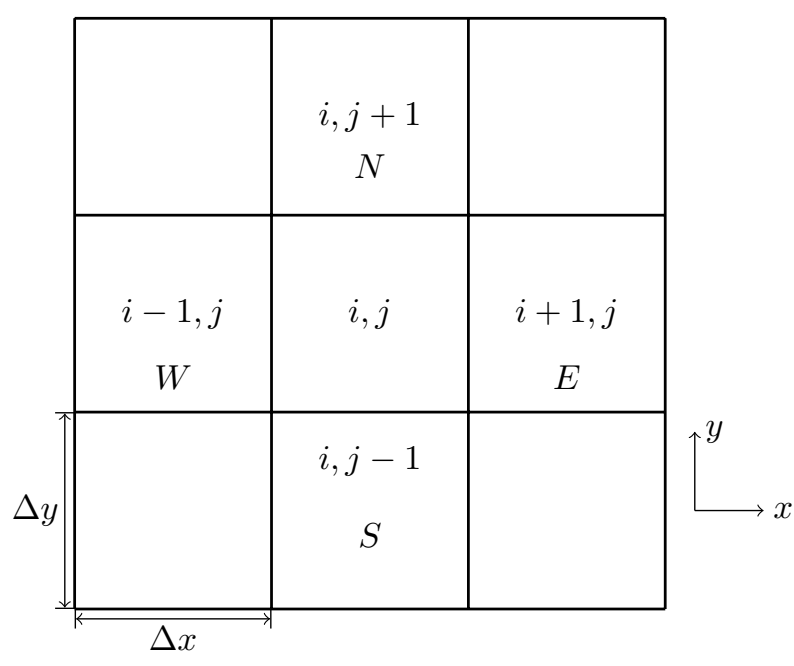

Gambar 2: Diskritisasi daerah perhitungan $\Omega$.

Misalkan domain citra dua dimensi $\Omega=\left[0, L_{x}\right] \times\left[0, L_{y}\right]$ dibagi menjadi $N \times M$ partisi, dengan $(N, M)>0 \in \mathcal{R}$, sehingga diskrit domain dapat didefinisikan sebagain $\mathcal{K}_{x}=\{0, \cdots, N\}$ dan $\mathcal{K}_{y}=$ $\{0, \cdots, M\}$ pada arah koordiant- $x$ dan $y$ berurutan $(x, y) \in \mathbf{R}^{2}$. Dimensi waktu $[0, T]$ juga dapat didiskritisasikan sebesar $N_{t}$ partisi dengan $\mathcal{T}=\left\{0, \cdots, N_{t}\right\}$. Sebagai tambahan, beberapa variabel didefiniskan sebagai berikut:

$$
\begin{aligned}
& \Delta x:=\frac{L_{x}}{N} \quad \Delta y:=\frac{L_{y}}{M}, \quad \Delta t:=\frac{T}{N_{t}}, \\
& x:=i \Delta x, \quad i \in \mathcal{K}_{x} \quad y:=j \Delta y, \quad j \in \mathcal{K}_{y} \quad y:=n \Delta t, \quad n \in \mathcal{T} .
\end{aligned}
$$

Dengan skema beda hingga FTCS (Forward Time Center Space) (lihat [15]), diskritisasi persamaan panas (2) dapat dibentuk sebagai berikut:

$$
\frac{I_{i, j}^{n+1}-I_{i, j}^{n}}{\Delta t}=\frac{I_{i+1, j}^{n}-2 I_{i, j}^{n}+I_{i-1, j}^{n}}{\Delta x^{2}}+\frac{I_{i, j+1}^{n}-2 I_{i, j}^{n}+I_{i, j-1}^{n}}{\Delta y^{2}}
$$

dengan $I_{i, j}^{n}=I(i \Delta x, j \Delta y, n \Delta t)$ dan $\Delta t>0$. 
Dalam penggunaan grid seragam $\Delta x=\Delta y=$ Constant, persamaan (8) dapat dituliskan kembali dalam bentuk:

$$
\begin{aligned}
I_{i, j}^{n+1} & =I_{i, j}^{n}+\lambda\left(I_{i+1, j}^{n}+I_{i-1, j}^{n}+I_{i, j+1}^{n}+I_{i, j-1}^{n}-4 I_{i, j}^{n}\right) \\
& =(1-4 \lambda) I_{i, j}^{n}+\lambda\left(I_{i+1, j}^{n}+I_{i-1, j}^{n}+I_{i, j+1}^{n}+I_{i, j-1}^{n}\right)
\end{aligned}
$$

dengan $\lambda=\Delta t / \Delta x^{2}$.

Untuk mempertahankan nilai $I_{i, j}^{n}$ selalu positif, maka diperlukan suatu syarat kestabilan dari skema diatas, yakni $(1-4 \lambda) \geq 0$ atau

$$
0 \leq \lambda \leq \frac{1}{4}
$$

Dengan cara yang sama, skema numerik untuk persamaan Perona-Malik (7) didapatkan sebagai berikut

$$
I_{i, j}^{n+1}=I_{i, j}^{n}+\lambda\left[\Psi_{N} \cdot \nabla_{N} I+\Psi_{S} \cdot \nabla_{S} I+\Psi_{E} \cdot \nabla_{E} I+\Psi_{W} \cdot \nabla_{W} I\right]_{i, j}^{n}
$$

dengan $N, S, W$, dan $E$ menyatakan pixel citra di atas, di bawah, di kiri dan di kanan pixel citra $(i, j)$ secara berurutan. Ilustrasi arah diskritisasi dapat dilihat pada Gambar 2.

\section{Penelitian Terkait}

Ide dari terbentuknya makalah ini adalah adanya beberapa referensi atau pustaka terkait selain yang sudah dibahas pada Bab I pendahuluan yaitu membahas tentang model anisotropic dan isotropic. Beberapa diantaranya adalah

- Lopez, et al., (2014) [8] dalam makalah yang berjudul "On the impact of anisotropic diffusion on edge detection", membahas bagimana cara mendeteksi tepi pada citra. Akan tetapi, dalam makalah tersebut model yang digunakan hanyalah model anisotropic dan metode numerik untuk menghampiri solusinya tidak dibahas secara detil.

- Wan, X., (2016) [20] dalam makalah yang berjudul "Research on the Novel Method of Edge Detection Based on the Isotropic Diffusion Model and Total Variation Model" membahas mengenai deteksi tepi menggunakan model difusi yakni model isotropic. Hasil yang diberikan sangat menjanjikan dan diimplementasikan pada beberapa gambar.

- Gupta et al., (2013) dalam makalah berjudul "Despeckling of SAR Images via an Improved Anisotropic Diffusion Algorithm" membahas tentang perbaikan dari algoritma anisotropic untuk gambar yang dihasilkan dari Synthetic Aperture Radar (SAR). Akan tetapi, makalah tersebut tidak membahas tentang deteksi tepi dari gambar melainkan digunakan untuk mempertajam gambar.

Dengan adanya referensi di atas, maka yang menjadi tantangan dalam makalah ini adalah membandingkan model isotropic dan anisotropic dalam beberapa gambar atau citra yang belum dilakukan oleh beberapa referensi di atas.

\section{HASIL DAN DisKUSI}

Pada bab ini, beberapa contoh hasil numerik menggunakan model isotropic diffusion dan anisotropic diffusion beserta pengukuran dengan histogram dan Peak Signal to Noise Ratio (PSNR) akan dipaparkan. Berikut rincian simulasi numerik yang akan diberikan:

1) Isotropic diffusion

- Citra MRI (Gambar 3)

- Citra Lena (Gambar 4)

2) Anisotropic diffusion

- Fluks eksponen (5) dan kuadratik (6) dengan $\kappa=0.35$

- Citra MRI dengan fluks eksponen (5) (Gambar 5)

- Citra Lena dengan fluks eksponen (5) (Gambar 6)

- Citra MRI dengan fluks kuadratik (6) (Gambar 7)

- Citra Lena dengan fluks kuadratik (6) (Gambar 8) 
IRYANTO ET.AL.

PENDEKATAN Numerik PADA MODEL ISOTROPIC...

- Fluks eksponen (5) dan kuadratik (6) dengan $\kappa=3.5$

- Citra MRI dengan fluks eksponen (5) (Gambar 9 atas)

- Citra MRI dengan fluks kuadratik (6) (Gambar 9 bawah)

3) Pengukuran

- Pengukuran dengan menggunakan histogram dan PSNR (Gambar 11 dan Gambar 12)

Hasil gambar yang ditampilkan berupa gambar dalam hasil pengolahan citra $I(x, y, t)$ dan dalam besarnya gradien $\nabla I(x, y, t)$. Adapun nilai parameter yang digunakan dalam simulasi dipilih sebagai berikut $\lambda=0.25, \Delta x=\Delta y=1$, dan $\Delta t=\lambda \times \Delta x^{2}=0.25$.

\section{A. Isotropic Diffusion}

Berikut akan diberikan hasil simulasi numerik pada pengolahan citra MRI dan Lena dengan menggunakan persamaan isotropic diffusion (2). Hasil untuk citra MRI dan Lena ditunjukkan pada Gambar 3 dan 4 secara berurutan. Deret waktu simulasi yang diberikan pada kedua gambar adalah $t=2,4,6,8 \mathrm{~s}$.
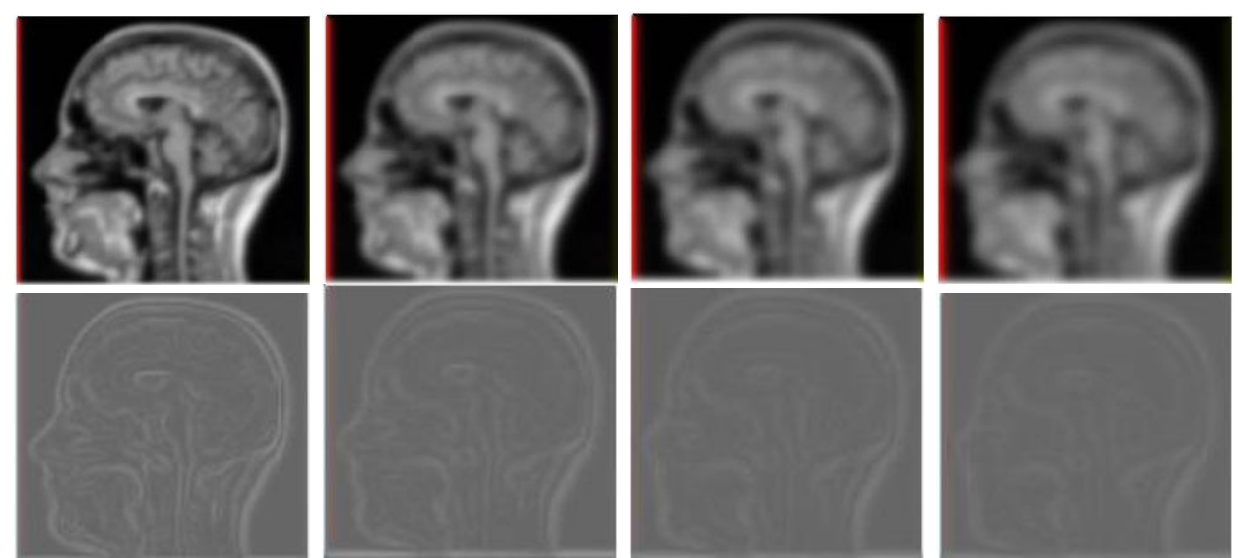

Gambar 3: Hasil citra MRI $(I(x, y, t))$ (atas) dan besarnya gradien $(\nabla I(x, y, t))$ (bawah) pada waktu $t=2,4,6$, 8 dengan menggunakan model isotropic diffusion.

Gambar 3 (atas) menunjukkan hasil citra $(I(x, y, t))$ pada deret waktu yang diberikan setelah diproses menggunakan model isotropic diffusion. Sedangkan untuk melihat garis tepi yang dihasilkan pada gambar yang sudah diproses, dapat dilihat dari besarnya gradien $(\nabla I(x, y, t))$ yang ditunjukkan pada Gambar 3 (bawah).
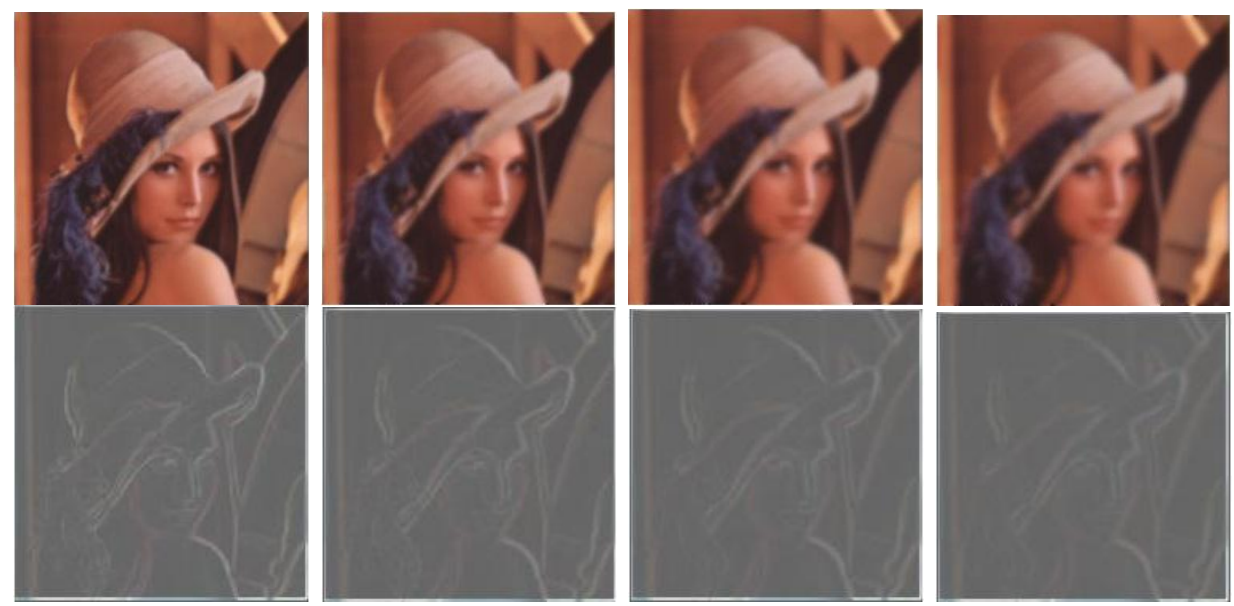

Gambar 4: Hasil citra Lena $(I(x, y, t))$ (atas) dan besarnya gradien $(\nabla I(x, y, t))$ (bawah) pada waktu $t=2,4,6$, 8 dengan menggunakan model Isotropic diffusion.

Hasil citra $(I(x, y, t))$ pada deret waktu yang diberikan setelah diproses menggunakan model isotropic diffusion ditampilkan pada Gambar 4 (atas). Sedangkan, gambar berdasarkan besarnya gradien $(\nabla$ 
$I(x, y, t))$ diperlihatkan pada Gambar 4 (bawah).

Terlihat pada Gambar 3 dan 4, bahwa dengan bertambahnya iterasi waktu $(t \rightarrow \infty)$, proses dengan model isotropic diffusion menghasilkan gambar yang semakin kabur (buram) dan menurunkan nilai informasi garis tepi pada gambar. Di sisi lain, garis tepi pada gambar merupakan informasi penting dari suatu citra sehingga garis tepi perlu dipertahankan. Sehingga, model isotropic diffusion tidak dapat digunakan untuk membedakan informasi yang perlu dipertahankan dengan yang perlu dihilangkan. Oleh karenanya, metode difusi linier kurang baik dalam pengolahan citra khususnya dalam tugas mempertahankan garis tepi pada gambar.

Pada subbab selanjutnya, akan ditunjukkan bahwa metode lain yaitu metode anisotropic diffusion sangat baik dalam pengolahan citra untuk mempertahankan garis tepi.

\section{B. Anisotropic Diffusion}

Dalam subbab ini, hasil pengolahan citra dengan menggunakan model anisotropic diffusion (7) akan dipaparkan lebih rinci. Simulasi dibuat dalam beberapa kelompok, pertama dengan menggunakan $\kappa=0.35$ dan fungsi fluks eksponen (5) dan kuadratik (6). Kedua, dengan menggunakan $\kappa=3.5$ dan fungsi fluks (5) dan (6).

\section{- Hasil citra menggunakan (5) dan (6) dengan $\kappa=0.35$}
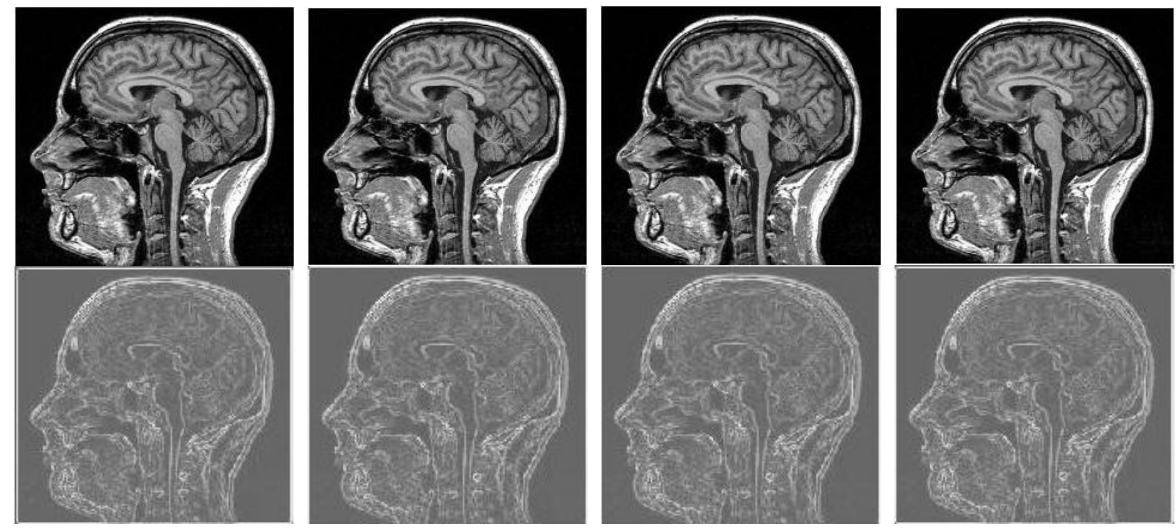

Gambar 5: Hasil citra MRI $(I(x, y, t))$ (atas) dan besarnya gradien $(\nabla I(x, y, t))$ (bawah) pada waktu $t=2$, 4, 6, 8 dengan menggunakan model anisotropic diffusion, fungsi fluks eksponen (5) dan $\kappa=0.35$.
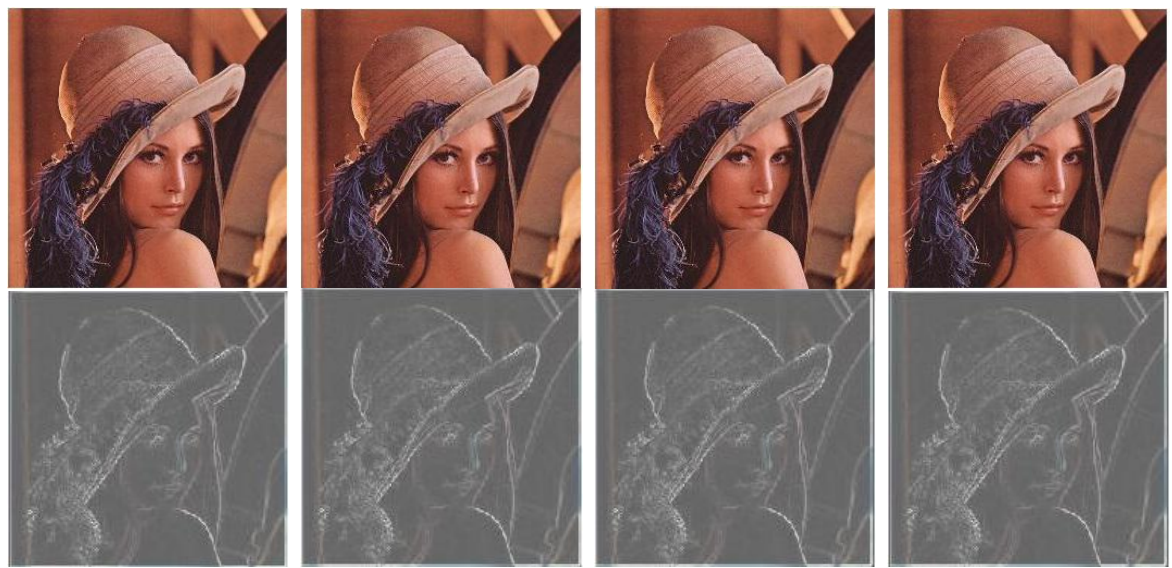

Gambar 6: Hasil citra Lena $(I(x, y, t))$ (atas) dan besarnya gradien $(\nabla I(x, y, t))$ (bawah) pada waktu $t=2$, 4, 6, 8 dengan menggunakan model anisotropic diffusion, fungsi fluks eksponen (5) dan $\kappa=0.35$. 
IRYANTO ET.AL.

PENDEKATAN NUMERIK PADA MODEL ISOTROPIC...
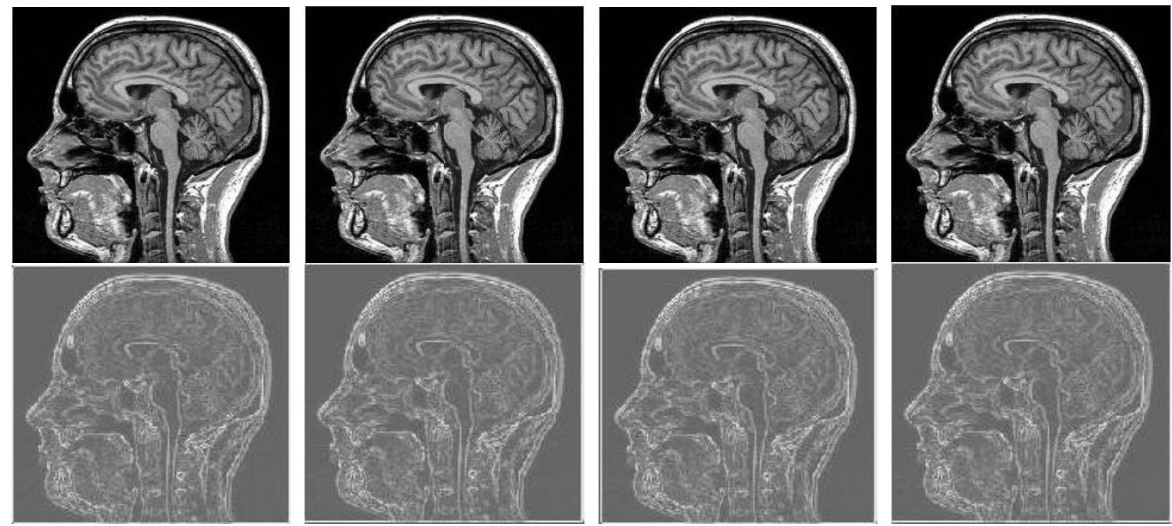

Gambar 7: Hasil citra MRI $(I(x, y, t))$ (atas) dan besarnya gradien $(\nabla I(x, y, t))$ (bawah) pada waktu $t=2$, 4, 6, 8 dengan menggunakan model anisotropic diffusion, fungsi fluks kuadratik (6) dan $\kappa=0.35$.
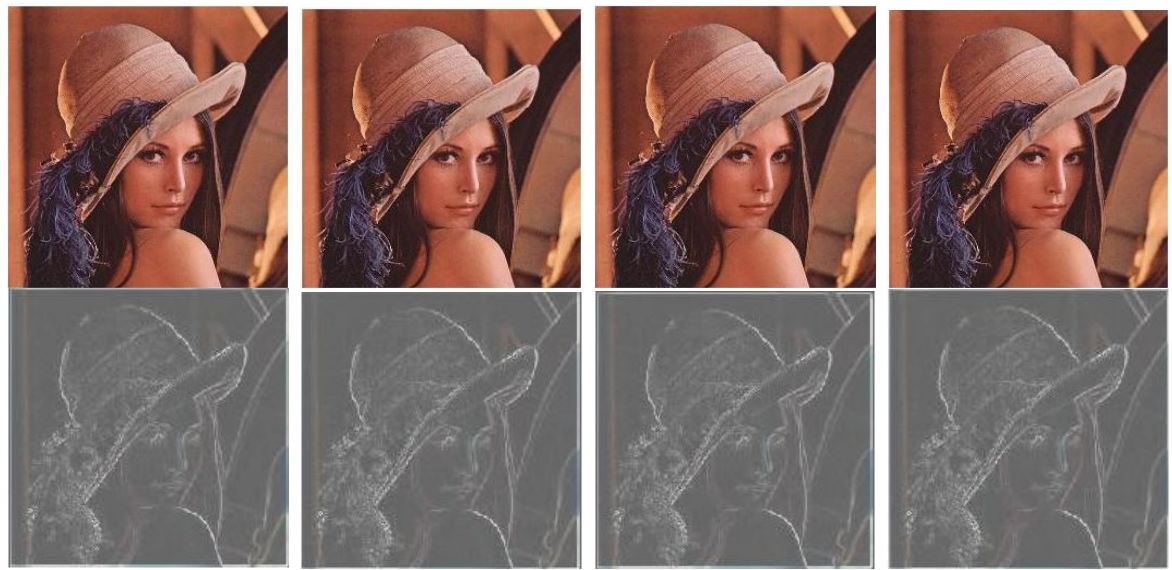

Gambar 8: Hasil citra Lena $(I(x, y, t))$ (atas) dan besarnya gradien $(\nabla I(x, y, t))$ (bawah) pada waktu $t=2$, 4, 6, 8 dengan menggunakan model anisotropic diffusion, fungsi fluks kuadratik (6) dan $\kappa=0.35$.

Dapat dilihat bahwa, dengan menggunakan fungsi fluks yang berbeda yaitu fluks eksponen (5) dan kuadratik (6), hasil pengolahan citra MRI dan Lena tidaklah begitu berbeda. Menggunakan kedua fluks, memperlihatkan hasil yang lebih tajam dibandingkan dengan menggunakan model isotropic diffusion pada subbab sebelumnya (Subbab V-A) meskipun seiring bertambahnya waktu $(t \rightarrow \infty)$.

Selebihnya, menggunakan model anisotropic diffusion, garis tepi gambar masih tetap dipertahankan seperti terlihat pada hasil gambar dengan besaran gradien $(\nabla I(x, y, t))$. Dua gambar yaitu gambar MRI dan Lena digunakan dalam simulasi ini. Informasi mengenai penggunaan nilai $\kappa=0.35$ pada hasil simulasi ini belum dapat dijelaskan pengaruhnya terhadap hasil citra. Akan tetapi, dengan melihat struktur persamaan (7), yaitu persamaan difusi, maka $\kappa$ secara fisis akan memperngaruhi kecepatan proses difusi atau dalam hal ini pada citra, mempercepat proses pengaburan. Berikut, akan diberikan tes kedua yaitu dengan menggunakan $\kappa=3.5$ serta masih menggunakan fungsi fluks (5) dan (6)

- Hasil citra menggunakan (5) dan (6) dengan $\kappa=3.5$

Pada model anisotropic diffusion yaitu menggunakan persamaan Perona-malik (7), koefisien difusi $\kappa$ sangatlah berperan penting dalam proses mempercepat difusi. Hasil simulasi sebelumnya menggunakan $\kappa=0.35$ dengan hasil gambar yang lebih bagus dibandingkan dengan model isotropic diffusion. Subbab ini akan ditujukan untuk melihat hasil pengolahan citra menggunakan $\kappa$ yang lebih besar, yaitu $\kappa=3.5$. Simulasi hanya akan menggunakan citra MRI. 

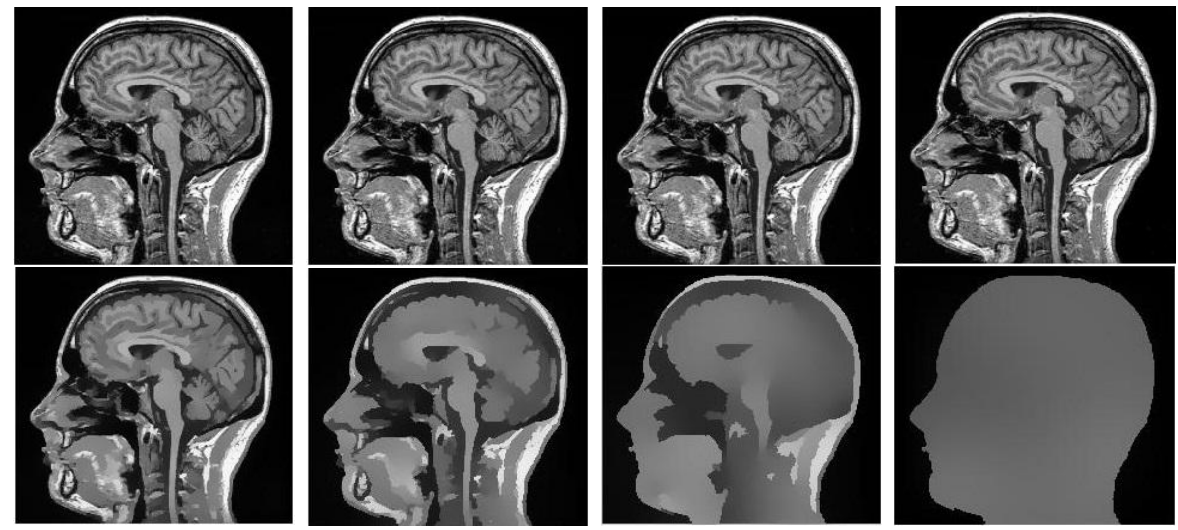

Gambar 9: Perbedaan hasil citra MRI $(I(x, y, t))$ menggunakan fungsi fluks (5) (atas) dan (6) (bawah) pada waktu $t=16,64,256,1024$ dan $\kappa=3.5$ pada model anisotropic diffusion.
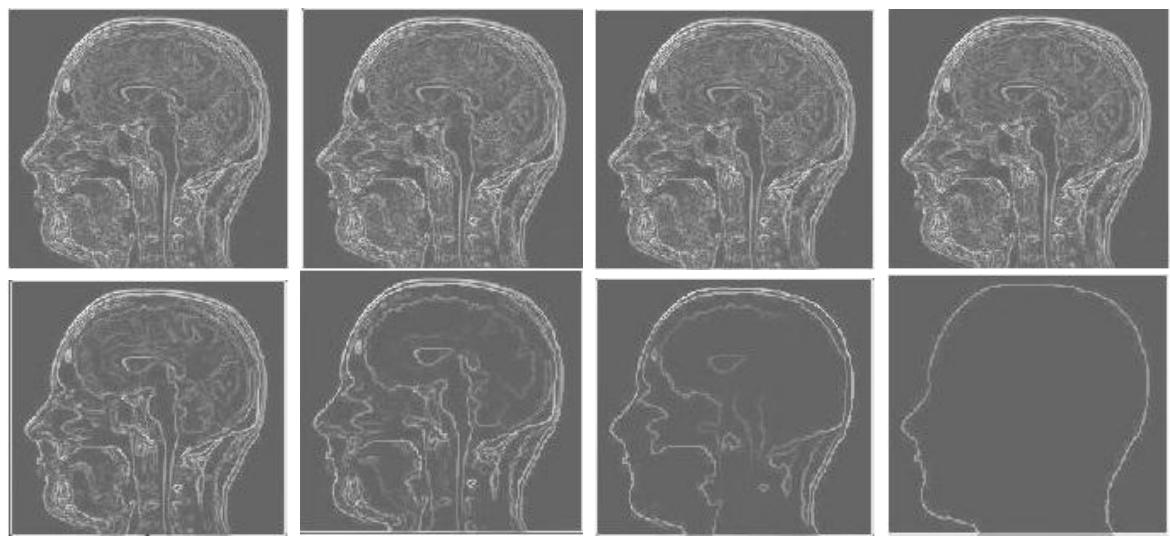

Gambar 10: Perbedaan hasil citra MRI dalam gradien $(\nabla I(x, y, t))$ menggunakan fungsi fluks (5) (atas) dan (6) (bawah) pada waktu $t=16,64,256,1024$ dan $\kappa=3.5$ pada model anisotropic diffusion.

Terlihat pada Gambar 9 dan 10, perbedaan yang sangat jelas yaitu hasil gambar menggunakan fluks eksponen (5) dengan fluks kuadratik (6) pada koefisein difusi $\kappa=3.5$. Pada Gambar 9, proses pengaburan citra dengan menggunakan fluks kuadratik (6) lebih cepat dibandingkan dengan menggunakan fluks eksponen (5). Informasi citra sudah tidak dapat lagi didapatkan dengan menggunakan fluks kuadratik (6).

Begitu juga dalam indetifikasi garis tepi, pada Gambar 10, terlihat bahwa fungsi fluks (5) lebih baik dalam hal mempertahankan garis tepi citra dibandingkan dengan fungsi fluks (6). Sehingga penggunaan $\kappa$ yang lebih besar mempengaruhi hasil untuk masing masing fluks yang digunakan. Pengukuran kualitas citra dari hasil pemrosesan yang telah dilakukan, dapat diukur dengan menggunakan histogram citra dan PSNR. Pada subbab berikutnya, pengukuran akan dijelaskan dengan lebih rinci.

\section{Pengukuran}

\section{Histogram Citra dan Peak Signal to Noise Ratio (PSNR)}

Pada subbab ini, analisis mengenai hasil pengolahan citra yang sudah dikerjakan pada subbab-subbab sebelumnya akan dipaparkan dengan rinci. Pertama, akan diperlihatkan perbandingan hasil histogram berupa:

- citra awal dengan noise Gauss sebesar $5 \mathrm{~dB}$,

- hasil isotropic diffusion,

- hasil anisotropic diffusion dengan fluks eksponen (5) dan

- hasil anisotropic diffusion dengan fluks kuadratik (6).

Hasil perbandingan citra pada waktu simulasi $t=16$ pada citra MRI ditunjukkan pada Gambar 11 . 
IRYANTO ET.AL.

PENDEKATAN NUMERIK PADA MODEL ISOTROPIC...

Sedangkan hasil histogram pada masing-masing gambar pada Gambar 11 ditunjukkan pada Gambar 12.
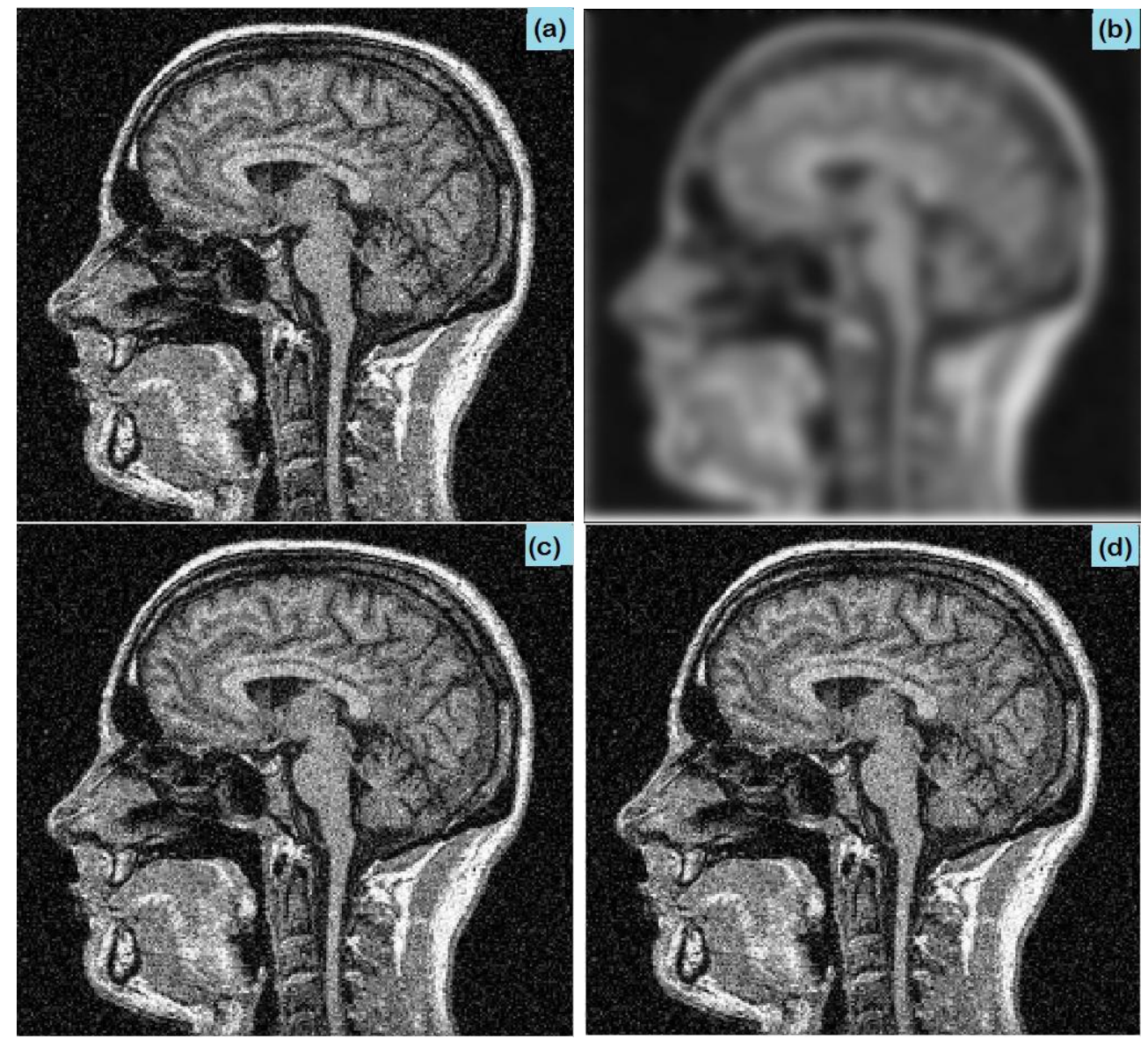

Gambar 11: Citra MRI untuk waktu $t=16$. (a) citra asli, (b) isotropic diffusion (2), (c) PME dengan fungsi fluks (5), (d) PME dengan fungsi (6).

Gambar 12 memperjelas hasil sebelumnya bahwa hasil pemrosesan citra menggunakan model isotropic diffusion (b) memiliki profil yang sangat jauh dibandingkan dengan profil citra awal $\left(I_{0}(x, y)\right)$ (a). Sedangkan dengan menggunakan model anisotropic diffusion, profil dalam fluks (5) (c) dan (6) (d) tidak begitu jauh dengan profil citra awal (a).

Masih dalam pembahasan pengukuran hasil simulasi, pengukuran menggunakan profil histogram hanya dapat dilakukan dengan kasat mata. Untuk melihat hasil pengukuran dengan berupa besaran angka, maka dibutuhkan pengukuran lain seperti dengan menggunakan Peak Signal to Noise Ratio $(P S N R)$.

Estimasi kualitas citra dapat ditunjukkan dengan PNSR. Nilai PNSR dapat di hitung dengan persamaan berikut ini

$$
P S N R=\frac{255 \times 255}{\frac{1}{N_{x} N_{y}} \sum_{i=1}^{N_{x}} \sum_{j=1}^{N_{y}}\left(I_{0}(i, j)-I(i, j)\right)^{2}}
$$

dengan $N_{x}$ dan $N_{y}$ berturut-turut menyatakan jumlah piksel arah horizontal dan vertikal. $I_{0}(i, j)$ dan $I(i, j)$ menyatakan citra awal dan citra perbaikan, lihat [21]. 
(a)

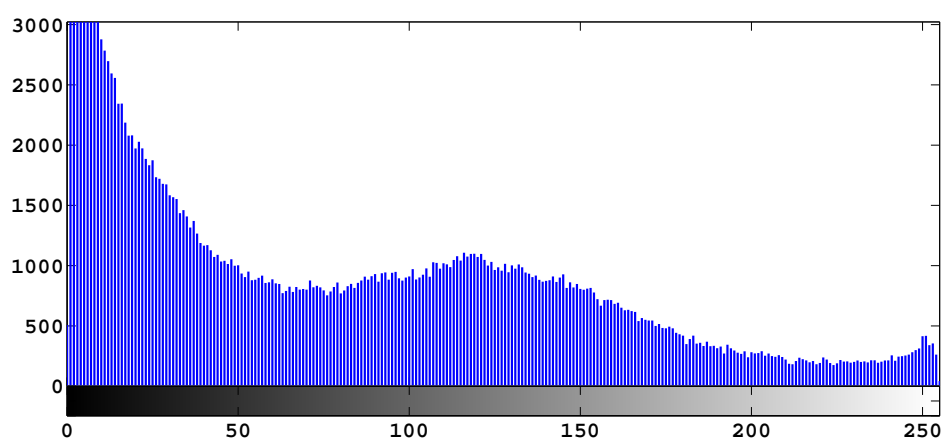

(b)
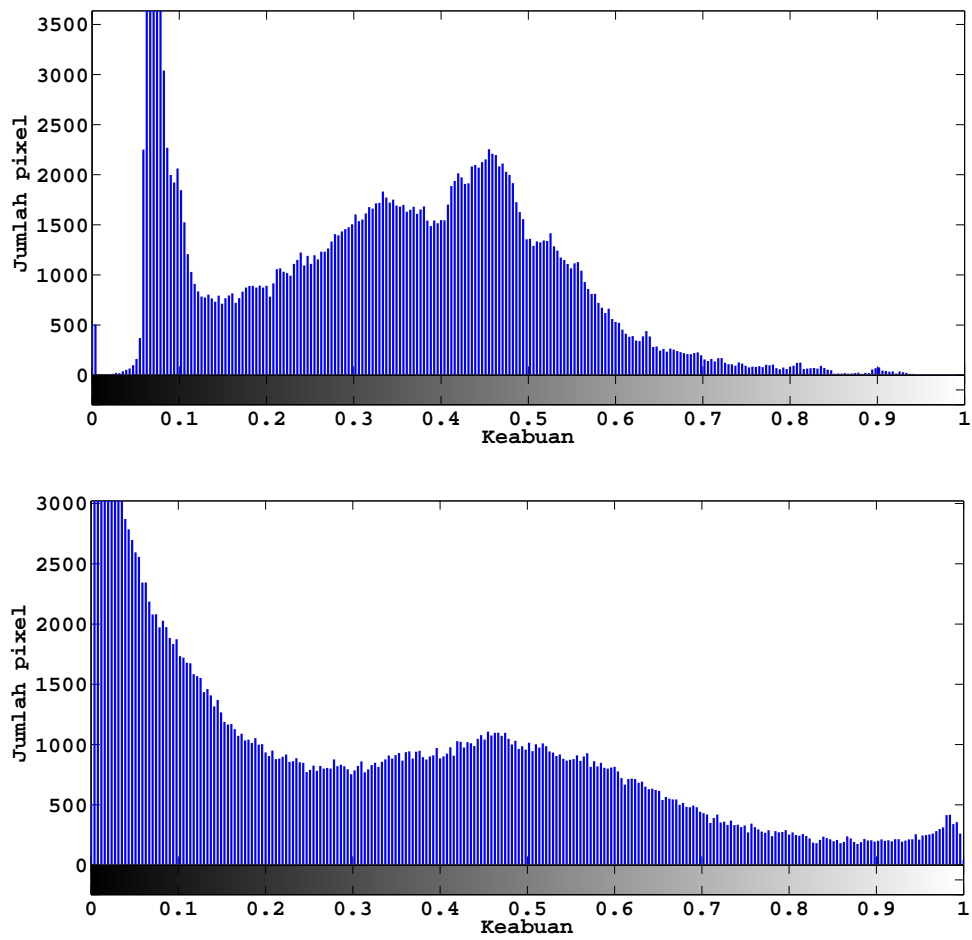

(c)

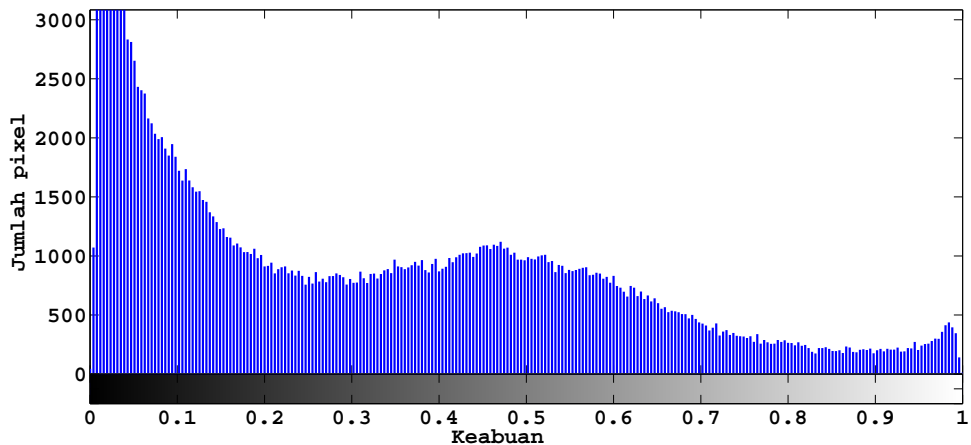

(d)

Gambar 12: Histogram citra MRI pada Gambar 11 untuk waktu $t=16$. (a) citra asli, (b) isotropic diffusion (2), (c) PME dengan fungsi fluks (5), (d) PME dengan fungsi (6).

Citra MRI yang ditunjukkan pada Gambar 11.(a) adalah citra awal dengan menambahkan noise Gauss sebesar 5 dB. Adapun besarnya PSNR untuk Gambar 11.(b), 11.(c), dan 11.(d) dapat dilihat pada tabel berikut

Perhatikan bahwa pada Tabel I, nilai PSNR untuk ketiga model tidak jauh berbeda namun secara visual dalam hal ini gambar histogram (Gambar 11) terlihat perbedaan yang signifikan. 
IRYANTO ET.AL.

PENDEKATAN NUMERIK PADA MOdEL ISOTROPIC...

Tabel I: Nilai PSNR untuk masing-masing simulasi.

\begin{tabular}{||c|c||}
\hline Model & PSNR \\
\hline \hline Gambar 11.(b) & $6.1745 \mathrm{~dB}$ \\
Gambar 11.(c) & $6.1833 \mathrm{~dB}$ \\
Gambar 11.(d) & $6.1833 \mathrm{~dB}$ \\
\hline
\end{tabular}

\section{KeSIMPULAN}

Simulasi numerik pada pengolahan citra untuk model isotropic dan inisotropic diffusion menggunakan metode beda hingga terpaparkan dengan rinci. Pengolahan citra dengan inisotropic diffusion menunjukkan hasil yang lebih baik dibandingkan hasil pengolahan citra dengan isotropic diffusion dalam mempertahankan garis tepi pada citra. Pada anisotropic diffusion, kedua fungsi fluks yaitu fungsi fluks eksponen (5) dan fungsi fluks kuadratik (6) memberikan perbedaan hasil yang sangat signifikan pada citra. Terutama dengan pemilihan nilai koefisien difusi $\kappa$ yang berpengaruh besar terhadap pemilihan jenis fluks. Pengukuran berupa histogram, sangat membantu secara visual membedakan hasil dari penggunaan model isotropic diffusion dan anisotropic diffusion. Dari hasil simulasi numerik pada citra MRI, PSNR untuk Gambar 11.(b), 11.(c), dan 11.(d) berturut-turut didapatkan sebesar $6.1745 \mathrm{~dB}, 6.1833 \mathrm{~dB}$, dan $6.1833 \mathrm{~dB}$. Dari hasil PSNR yang didapat dengan gambar berbeda menghasilkan nilai sama. Hal ini sering terjadi karena adanya pengaruh noise yang diberikan pada kedua gambar sama. PSNR bukanlah satu-satunya cara untuk memvalidasi hasil dari pengolahan citra, hasil validasi yang paling tepat adalah dengan visual/melihat secara langsung perubahan citra yang dihasilkan.

\section{PUSTAKA}

[1] Afzal Ahmed, Masahiko Nagai, Chen Tianen, and Ryosuke SHIBASAKI. Uav based monitoring system and object detection technique development for a disaster area. International Archives of Photogrammetry, Remote Sensing and Spatial information Sciences, 37:373-377, 2008.

[2] Gilles Aubert and Pierre Kornprobst. Mathematical problems in image processing: partial differential equations and the calculus of variations, volume 147. Springer Science \& Business Media, 2006.

[3] Jian Bai and Xiang-Chu Feng. Fractional-order anisotropic diffusion for image denoising. IEEE transactions on image processing, 16(10):2492-2502, 2007.

[4] Nicolas Crouseilles, Matthieu Kuhn, and Guillaume Latu. Comparison of numerical solvers for anisotropic diffusion equations arising in plasma physics. Journal of Scientific Computing, 65(3):1091-1128, 2015.

[5] Bekir Dizdaroglu. Solving heat flow equation for image regularization. 2010.

[6] Carsten Ebmeyer and Jens Vogelgesang. Finite element approximation of a forward and backward anisotropic diffusion model in image denoising and form generalization. Numerical Methods for Partial Differential Equations, 24(2):646-662, 2008.

[7] Patrick Guidotti. Anisotropic diffusions of image processing from perona-malik on. Advanced Studies in Pure Mathematics, 99:20XX, 2015.

[8] Carlos Lopez-Molina, Mikel Galar, Humberto Bustince, and Bernard De Baets. On the impact of anisotropic diffusion on edge detection. Pattern Recognition, 47(1):270-281, 2014.

[9] David Mumford and Jayant Shah. Optimal approximations by piecewise smooth functions and associated variational problems. Communications on pure and applied mathematics, 42(5):577-685, 1989.

[10] U Niethammer, S Rothmund, MR James, J Travelletti, and M Joswig. Uav-based remote sensing of landslides. International Archives of Photogrammetry, Remote Sensing and Spatial Information Sciences, 38(Part 5):496-501, 2010.

[11] Hardik Pandit and DM Shah. Application of digital image processing and analysis in healthcare based on medical palmistry. Int J Comput Appl, 2011.

[12] Pietro Perona and Jitendra Malik. Scale-space and edge detection using anisotropic diffusion. Pattern Analysis and Machine Intelligence, IEEE Transactions on, 12(7):629-639, 1990.

[13] Vid Peterman. Landslide activity monitoring with the help of unmanned aerial vehicle. The International Archives of Photogrammetry, Remote Sensing and Spatial Information Sciences, 40(1):215, 2015.

[14] Yoniar Hufan Ramadhani, Rokhmatulloh Rokhmatulloh, Aris Poniman, and Rahmatia Susanti. Pemetaan pulau kecil dengan pendekatan berbasis objek menggunakan data unmanned aerial vehicle (uav). MAJALAH ILMIAH GLOBE, 17(2), 2015.

[15] L. Burden Richard and J. Faires Douglas. Numerical Analysis 9th ed. Brooks/Cole, Cengage Learning, 2011.

[16] Catur Aries Rokhmana. The potential of uav-based remote sensing for supporting precision agriculture in indonesia. Procedia Environmental Sciences, 24:245-253, 2015.

[17] Esther Salamí, Cristina Barrado, and Enric Pastor. Uav flight experiments applied to the remote sensing of vegetated areas. Remote Sensing, 6(11):11051-11081, 2014

[18] R Shofiyati. Teknologi pesawat tanpa awak untuk pemetaan dan pemantauan tanaman dan lahan pertanian. Informatika Pertanian, 20(2):58-64, 2011. 
[19] Kishore C Swain, HP W Jayasuriya, and VM Salokhe. Low-altitude remote sensing with unmanned radio-controlled helicopter platforms: A potential substitution to satellite-based systems for precision agriculture adoption under farming conditions in developing countries. Agricultural Engineering International: CIGR Journal, 2007.

[20] Xiaoming Wan. Research on the novel method of edge detection based on the isotropic diffusion model and total variation model. Cybernetics and Information Technologies, 16(5):97-108, 2016.

[21] Guo W Wei. Generalized perona-malik equation for image restoration. Signal Processing Letters, IEEE, 6(7):165-167, 1999.

[22] Joachim Weickert. A review of nonlinear diffusion filtering. In Scale-space theory in computer vision, pages 1-28. Springer, 1997.

[23] Joachim Weickert. Anisotropic diffusion in image processing, volume 1. Teubner Stuttgart, 1998.

[24] Maciek Wielgus. Perona-malik equation and its numerical properties. arXiv preprint arXiv:1412.6291, 2014.

[25] Wenqian Zang, Jiayuan Lin, Yangchun Wang, and Heping Tao. Investigating small-scale water pollution with uav remote sensing technology. In World Automation Congress (WAC), 2012, pages 1-4. IEEE, 2012. 
